\title{
An Approach to Renewable Energies Course for Energy Engineering Students in the Framework of the European Higher Education Area (EHEA)
}

\author{
Herminio Martínez-García and Encarna García-Vílchez \\ Department of Electronics Engineering \\ Eastern Barcelona School of Engineering (Escola d'Enginyeria de Barcelona Est, EEBE) \\ Technical University of Catalonia (UPC). BarcelonaTech \\ Diagonal-Besòs Campus. Eduard Maristany Ave., nº 10 - 14 \\ E-08019 - Barcelona. SPAIN \\ E-mail: herminio.martinez@upc.edu
}

\begin{abstract}
As it is well known, the Bologna Process is a voluntary intergovernmental European cooperation initiative that led to the creation of the named European Higher Education Area (EHEA). EHEA was formed to promote mobility, increase academic recognition and attract students and staff from around the world to Europe. On the other hand, since September 2016, the Technical University of Catalonia (Universitat Politècnica de Catalunya, UPC) - BarcelonaTech has a new Campus in Barcelona City, the Diagonal-Besòs Campus. In this new Campus appears the Eastern Barcelona School of Engineering (Escola d'Enginyeria de Barcelona Est, EEBE), with new Bachelor's and Master's Degrees. In this framework, also since September 2016, the EEBE is offering the new 4-year Bachelor's Degree in Energy Engineering with a total number of 240 ECTS credits. Current article deals with the inclusion of the course about sizing and design of renewable energy systems in the context of this degree. In particular, and although this topic was eventually abandoned in the initial degree curriculum, the paper presents the development of a $3^{\text {rd }}$-year course, Renewable Energies, that focuses on this topic.
\end{abstract}

Keywords-University Education; Bologna Process; European Higher Education Area (EHEA); Energy Engineering Degree; Renewable Energy Systems Course.

\section{INTRODUCTION}

Initially, the Bologna Process was started in the year 1998 (Sorbonne Declaration) by four countries (France, Germany, Italy, and the UK). From 1999, when the Bologna Declaration was launched, more countries joined. The European Higher Education Area (EHEA) was launched along with the Bologna Process' decade anniversary, in March 2010, during the Budapest-Vienna Ministerial Conference. At the same time, it was decided to continue the Bologna Process, at least until the year 2020 [1], [2].

As the main objective of the Bologna Process since its inception in 1999, the EHEA was meant to ensure more comparable, compatible and coherent systems of higher education in Europe. Between years 1999 and 2010, all the efforts of the Bologna Process members were targeted to creating the European Higher Education Area, that became reality with the Budapest-Vienna Declaration of March, 2010. During current decade, the consolidation of EHEA will be aimed.

\section{CurRent BACHElor's DEgREe IN THE EASTERN BARCELONA SCHOOL OF ENGINEERING (EEBE)}

Since September 2016, the Technical University of Catalonia (Universitat Politècnica de Catalunya, UPC) BarcelonaTech has a new Campus in Barcelona city, Spain, the Diagonal-Besòs Campus. In this new Campus appears the Eastern Barcelona School of Engineering (Escola d'Enginyeria de Barcelona Est, EEBE), with new Bachelor's and Master's Degrees [4]. This new school derives from the old Barcelona College of Industrial Engineering (Escola Universitària d'Enginyeria Tècnica Industrial de Barcelona, EUETIB), which was a higher education institution associated to the UPC [5].

The Barcelona College of Industrial Engineering (EUETIB), which, with over 110 years of history, has been (since 1904) forming industrial experts, industrial engineers and engineering graduates over decades, focusing on four classic specialties of the industrial sector: Industrial Chemical Engineering, Mechanical Engineering, Industrial Electrical Engineering, and Industrial Electronics Engineering [5].

In 2009, the final extinction of Industrial Engineering plan (Spanish Plan 2002) was carried out, and the Center starts Engineering studies in the industrial field under the guidance of well-known Bologna Process and the framework of the European Higher Education Area (EHEA). Finally, after more than a century, this center associated to the UPC closed its doors in July 2016, and the aforementioned Eastern Barcelona School of Engineering (EEBE) begins operating in September 2016 in the new Diagonal-Besòs Campus.

In September 2016, the Center starts bachelor's and master's degrees (and some Ph.D. programmes), also under the framework of the Bologna Process and the European Higher 
Education Area (EHEA). In particular, the Bachelor's Degrees studies taught at the EEBE (also in the industrial field) are the following [4]:

- Degree in Industrial Electronics and Automation Engineering.

- Degree in Energy Engineering.

- Degree in Electrical Engineering.

- Degree in Biomedical Engineering.

- Degree in Mechanical Engineering.

- Degree in Chemical Engineering.

- Degree in Materials Engineering.

In this context, the Eastern Barcelona School of Engineering is offering the 4-year Bachelor's Degree in Energy Engineering since 2016 with a total number of ECTS credits [3] of 240 [6].

As it can be appreciated in Table I, credits are divided into the four academic courses with a structure of the degree that has five blocks clearly distinguished: Blue-color boxes for basics education for engineering context; salmon-color boxes for common courses in the Industrial Engineering context; green-color boxes for particular specialization courses in the Energy Engineering; yellow-color boxes for elective courses; and, finally, violet-color box for the Degree Final Project. All these credits are divided into the four academic courses with a structure of the degree that has four blocks clearly distinguished (Table I):

- During the first year, the degree focuses on common courses in basics education for Engineering context (total 60 ECTS credits): Mathematics (18 ECTS), Physics (12 ECTS), Chemistry (6 ECTS), Computer
Science (6 ECTS), Graphic Expression (6 ECTS), Materials Science (6 ECTS), and Technology Environmental Technologies and Sustainability (6 ECTS).

- During the second year, the degree focuses on common courses but in the Industrial Engineering context (total 48 ECTS): Statistics (6 ECTS), Electrical Systems (6 ECTS), Electronics Systems (6 ECTS), Industrial Control and Automation (6 ECTS), Mechanical Systems (6 ECTS), Fluid Mechanics (6 ECTS), Thermodynamics and Heat Transfer (6 ECTS), Business (6 ECTS). In addition, the degree starts with specialization courses in the Energy Engineering context (total 12 ECTS), including both Energy Resources (6 ECTS), and Electrical Energy Generation (6 ECTS).

- During the third year, the degree focuses on specialization courses in the Energy Engineering context (total 54 ECTS): Energy Fluid Transmission and Distribution (6 ECTS), Electrical Energy Transmission and Distribution (6 ECTS), Thermal and Fluid Dynamic Power Generation (6 ECTS), Power Plant Technology (6 ECTS), Energy Sector Regulations (6 ECTS), Efficiency and Energy Audits (6 ECTS), Energy Storage (6 ECTS), Static Energy Converters (6 ECTS), and Control of Energy Systems (6 ECTS). In addition, students study a last course in the Industrial Engineering context: Engineering Design (6 ECTS).

- Finally, during the fourth year, the degree focuses on the two last specialization courses in the Energy Engineering context (total 12 ECTS): Integration and

TABLE I. STRUCTURE OF THE 4-YEAR BACHELOR'S DEGREE IN ENERGY ENGINEERING OFFERED AT THE EASTERN BARCELONA SCHOOL OF ENGINEERING (ESCOLA D'ENGINYERIA DE BARCELONA EST, EEBE) OF THE TECHNICAL UNIVERSITY OF CATALONIA (UNIVERSITAT POLITÈCNICA DE CATALUNYA, UPC) - BARCELONATECH [6]. THE CREDITS ARE DIVIDED INTO THE FOUR ACADEMIC COURSES WITH A STRUCTURE OF THE DEGREE THAT HAS FOUR BLOCKS CLEARLY DISTINGUISHED (BLUE, SALMON, GREEN AND YELLOW BOXES).

\begin{tabular}{|c|c|c|c|c|c|}
\hline Q1 & Calculus & $\begin{array}{c}\text { Physics I: } \\
\text { Fundamentals of } \\
\text { Mechanics }\end{array}$ & $\begin{array}{l}\text { Computer } \\
\text { Science }\end{array}$ & $\begin{array}{l}\text { Graphic } \\
\text { Expression }\end{array}$ & Chemistry \\
\hline Q2 & $\begin{array}{c}\text { Algebra and } \\
\text { Multivariable } \\
\text { Calculus }\end{array}$ & $\begin{array}{l}\text { Numerical Calculus. } \\
\text { Differential Equations }\end{array}$ & $\begin{array}{c}\text { Physics II: Fundamentals } \\
\text { of Electromagnetism }\end{array}$ & $\begin{array}{c}\text { Materials Science } \\
\text { and Technology }\end{array}$ & $\begin{array}{c}\text { Environmental } \\
\text { Technologies and } \\
\text { Sustainability }\end{array}$ \\
\hline Q3 & Statistics & $\begin{array}{c}\text { Fluid } \\
\text { Mechanics }\end{array}$ & $\begin{array}{l}\text { Mechanical } \\
\text { Systems }\end{array}$ & $\begin{array}{c}\text { Electrical } \\
\text { Systems }\end{array}$ & $\begin{array}{c}\text { Energy } \\
\text { Resources }\end{array}$ \\
\hline Q4 & Business & $\begin{array}{c}\text { Thermodynamics and } \\
\text { Heat Transfer }\end{array}$ & $\begin{array}{c}\text { Industrial Control and } \\
\text { Automation }\end{array}$ & $\begin{array}{c}\text { Electronics } \\
\text { Systems }\end{array}$ & $\begin{array}{c}\text { Electrical Energy } \\
\text { Generation }\end{array}$ \\
\hline Q5 & Engineering Design & $\begin{array}{c}\text { Energy Fluid } \\
\text { Transmission and } \\
\text { Distribution }\end{array}$ & $\begin{array}{l}\text { Energy Sector } \\
\text { Regulations }\end{array}$ & $\begin{array}{l}\text { Efficiency and } \\
\text { Energy Audits }\end{array}$ & $\begin{array}{c}\text { Thermal and Fluid } \\
\text { Dynamic Power } \\
\text { Generation }\end{array}$ \\
\hline Q6 & $\begin{array}{c}\text { Control of Energy } \\
\text { Systems }\end{array}$ & $\begin{array}{c}\text { Electrical Energy } \\
\text { Transmission and } \\
\text { Distribution }\end{array}$ & $\begin{array}{l}\text { Energy } \\
\text { Storage }\end{array}$ & $\begin{array}{l}\text { Static Energy } \\
\text { Converters }\end{array}$ & $\begin{array}{l}\text { Power Plant } \\
\text { Technology }\end{array}$ \\
\hline Q7 & $\begin{array}{c}\text { Production } \\
\text { Organisation }\end{array}$ & $\begin{array}{c}\text { Integration and } \\
\text { Management of Energy } \\
\text { Systems }\end{array}$ & $\begin{array}{l}\text { Renewable } \\
\text { Energies }\end{array}$ & $\begin{array}{l}\text { Elective } \\
\text { Course }\end{array}$ & $\begin{array}{l}\text { Elective } \\
\text { Course }\end{array}$ \\
\hline Q8 & $\begin{array}{l}\text { Elective } \\
\text { Course }\end{array}$ & & $\begin{array}{r}\text { Degree Fi } \\
\text { Project }\end{array}$ & & \\
\hline
\end{tabular}


Management of Energy Systems, and Renewable Energies (6 ECTS) [7]; elective courses (18 ECTS), and the degree final project (24 ECTS).

\section{Course on REnEwable Energies}

The authors of this article have focused mainly on the latter teaching degree (Energy Engineering), object of this work. The teaching of the authors has focused on two areas of this degree: Firstly, core courses in the third year of the degree, and, secondly, elective courses of fourth year. In addition, these elective courses are usually combined with the obtaining of the Bachelor's thesis (BT).

As it can be observed in Table I, there are specific courses on renewable energies in the new study planning of the degree and, in particular, on solar and wind energy systems, and highefficiency energy conversion. It is important to highlight that in the course Energy Resources (6 ECTS) [6], taught in the $3^{\text {rd }}$ semester ( $2^{\text {nd }}$ year, semester Q3), the sun as an energy source is dealt (including some aspects such as interest of the solar energy, potential, etc.). However, specifically, the sizing and design of renewable (especially, solar and wind) energy systems are not dealt in this course.

As a consequence, the current teaching staff of the degree should find a solution to teach this essential part of Energy Engineering field. The solution was to consider this matter as the content of the course Renewable Energies, located in the $7^{\text {th }}$ semester $\left(4^{\text {th }}\right.$ year, semester Q7) [7]. This course consists of 45 classroom hours / semester ( $3 \mathrm{~h} /$ week) and 15 laboratory hours /semester ( $2 \mathrm{~h} /$ fortnight).

Therefore, as a consequence, the structure of the course consists of the following topics [7]:

- DC-DC energy conversion and battery regulators in the framework of the renewable energy systems.

- DC-AC energy conversion and solar inverters.

- $\quad$ Sizing of PV solar energy systems.

- $\quad$ Sizing of thermal solar energy systems.

- Sizing of water pumping based on photovoltaic solar energy.

- $\quad$ Sizing of wind energy systems.

- Integration of solar and wind energy systems in the grid.

\section{GUIDED ACTIVITY (GA) AT THE EASTERN BARCELONA SCHOOL OF ENGINEERING (EEBE)}

At the EEBE, the contents that are current curricula have been chosen to divide them into biannual courses of 6 ECTS credits each, except for some very particular courses such as the English Technical Communication, also biannual, but with 9 ECTS credits. Thus, a course of 6 ECTS credits, especially those that are part of the degree specialty (core or elective), has its structure divided into the following four blocks (Figure 1):

- $\quad 1.2$ ECTS credits for lectures (corresponding to 2 $\mathrm{h} /$ week).

- 0.6 ECTS credits for classes of problems (corresponding to $1 \mathrm{~h} /$ week).
- 0.6 ECTS credits for laboratory sessions, also corresponding to $1 \mathrm{~h} /$ week, but grouped into fortnightly sessions of $2 \mathrm{~h}$ (Fig. 2).

- $\quad 3.6$ ECTS credits of non-presential (NP) activities and guided activities (GA) (corresponding to 6 $\mathrm{h} /$ week).

In this figure, it is important to highlight that most workload involved in a particular course, and that the student must complete throughout the semester, is framed within 3.6 ECTS credits for non-presential off-site activities (NP) and guided activities (GA). In general, in these credits, course students must complete activities, tasks, works, etc., related, among others, to the following:

- Making activities, problems, etc., concerning topics explicitly explained or not by course professors in lectures, problem sessions and/or laboratory.

- Research, development and/or preparation by students of some topics that are not explained in class by course professors.

- Making reports of practice relating to laboratory sessions conducted in the course throughout the semester.

- Implementation of physical prototypes of energy plants, systems or equipment within the field of industrial engineering that is being considered in the course throughout the semester.

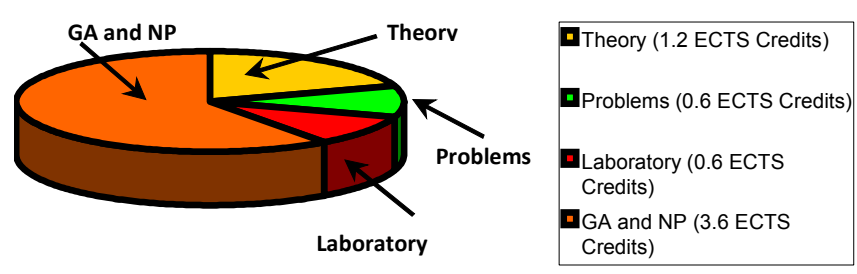

Fig. 1. Distribution of ECTS credits in current degree courses taught at the EEBE.

As it is well known, technical studies, especially those related to engineering, require a highly recommended (and, indeed, almost necessary) practical aspect. It serves not only as key from a practical point of view of this typology of University degrees, but also it can be used as a motivational tool to current students and future engineers.

This is a special key in engineering studies related to Energy Engineering. Indeed, the student of Energy Engineering, in addition of requiring theory course blocks that are used to analyze and design energy systems, plants and equipments (related to the lower levels of Bloom's taxonomy: Knowledge, comprehension, application and analysis), it also requires a special dedication to the simulation, assembly (implementation) and testing of these blocks, systems and equipments that have been designed or have been previously discussed in lectures. These tasks correspond to the higher levels of the aforementioned Bloom's taxonomy: Synthesis and evaluation. While these levels of depth is not always done, due to time limitation or level of the course (staying at lower 


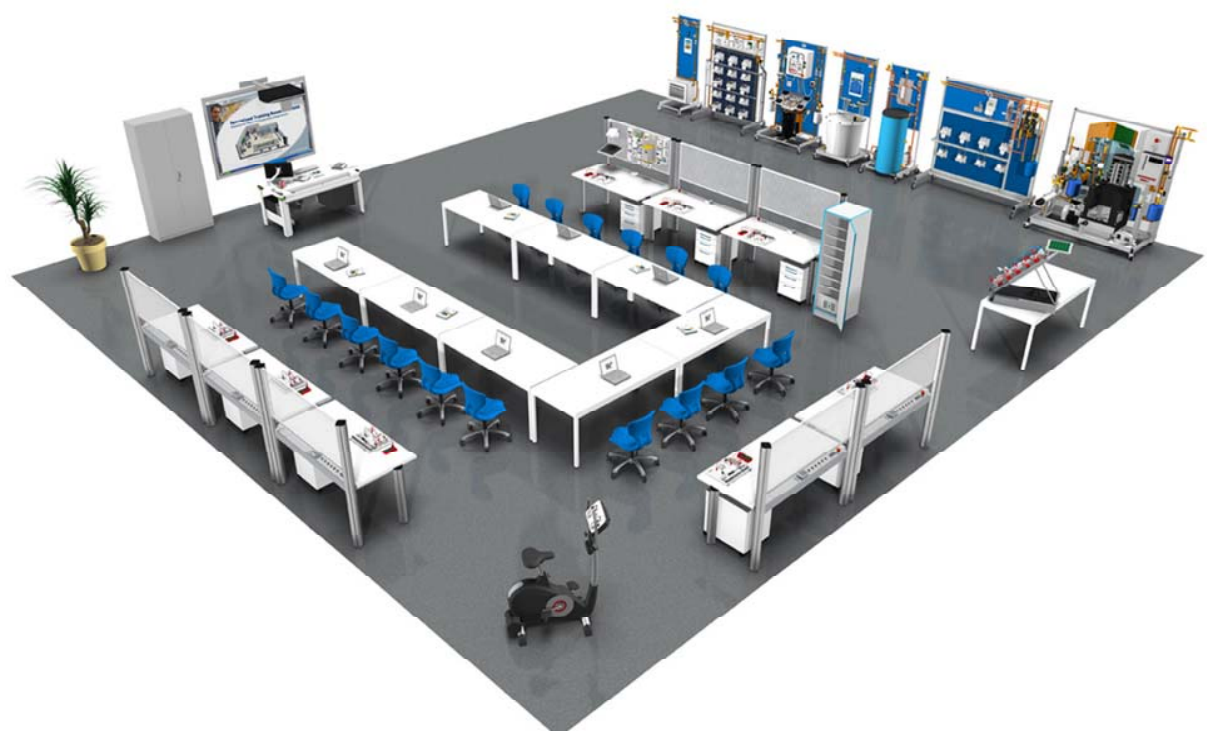

Fig. 1. Distribution of the renewable energy laboratory.

levels), in finalist courses of the degree it is important to reach these last Bloom's taxonomy levels, in order to carry out the idea of "globalization" for bachelor's degree students.

This objective, unfortunately, is not always achieved. Moreover, if these finalists courses (usually elective courses) work together these "global" aspects within a common framework, the results can be quite encouraging.

The idea of cooperative learning-based activity that is explained in this paper started as a result of the detection by course professors of a lack of students' motivation and academic level and capacity of the Bachelor degree in Energy Engineering.

Concerning undergraduate studies in Energy Engineering, within this load of guided activities, special emphasis is focused on the design, simulation, physical implementation (if it is possible) and test of a prototype energy plant, system or equipment. Indeed, all this process involves different stages which refer to all the actual process of developing energy plants, systems or equipment in an industrial or professional environment that students will encounter in a near future in their professional career:

- Design of the different single blocks of the energy plant, system or equipment to be carried out.

- Simulation of the aforementioned blocks individually, and simulation of the complete set when interconnection between them are carried out.

- If required or it is possible, physical implementation of the aforementioned individual blocks that form the system to carry out.

- If required or it is possible, testing of these individual blocks and experimental corroboration of their operation.

- If required or it is possible, assembly and installation of the blocks in order to obtain the complete plant, system or equipment.
- If required or it is possible, testing, experimental corroboration and obtaining of experimental results of the complete system or equipment carried out.

- Making of a technical report covering the entire process carried out, simulation results, experimental measures, economic budget, etc.

- Oral defense, with limited time, of the accomplished project carried out.

The development of this project is named in the course cross project. Therefore, having into account previous contents (mentioned in Section 3), the course cross project normally consists of the design, simulation, and (if it is possible) physical assembly, implementation and testing of an energy plant, system or equipment. Some examples of cross projects are, for instance, the design and simulation of a complete PV solar or wind plant to supply the energy requirements of a village, or the design, simulation and experimental implementation of a battery charger based on power DC/DC converters (buck, boost, etc.).

\section{EVALUATION AND REMARKS OF THE EXPERIENCE CARRIED OUT}

Notice that the authors of this paper do not have historic data since this course (fall semester of the academic year 201617 ) is the first time the course is taught at EEBE. Therefore, they have feedback from the students only for this single semester.

Regardless of qualifications, to assess the activity carried out, information reported by the 'affected' people (i.e., course students) was used. It is important to highlight, after several detailed talks subsequent to the presentation and defense of the cross project, the good reception of the experience by students, although, in some groups, the results were not fully satisfactory (marks below 7 on a total of 10 points).

For most students, it was not the first time performed an evaluation experience of this kind. In fact, in different core 
courses shown in Table I (e.g., Energy Resources, or Electrical Energy Generation), a part of the course includes the design, simulation, implementation and experimental corroboration of the operation for a more limited plant or system. In them, the goal is that the system has a good defined purpose, within the scope of the course itself, but its dimensions are generally dimensioned so that the same dedication from the student is limited. In this case, however, the cross project has a much larger and contained in different courses, although they are in the same area, try different topics within the field of Energy Engineering.

However, despite the difficulty and dedication that students have shown in collected opinions, they expressed a number of strengths of the activity. From these points, there are three that should be emphasized:

- The development and progress of the cross project task are similar to a project that would take place in a company by a group of engineers. Therefore, the involved courses (and their contents), and, in general, the degree, focus on the imminent professional world for these students.

- Eliminates the "tightness" that currently many of courses taught in the Spanish University have. Our students often see degree courses as a separate part from the other courses, not only for different semesters, but even for courses taught simultaneously in the same semester. For them, it is difficult to integrate and globalize different degree courses (core or not) in a common framework. According to students, the cross project largely eliminates this sealing. As mentioned before, the idea of globalization, content integration and coordination is key point.

- It allows students to focus their Bachelor's thesis (BT) on a topic close to the cross project or close to one of the courses included in the intensification that serves as framework for the cross project. This idea is also key point to many students who are intensifying as a way to focus their careers in a certain area within the field of Energy Engineering.

Finally, as future research by part of coauthors of this study, we want to make a series of progressive improvements in the procedure carried out, which involves the following points:

- $\quad$ Organize the cross project as a learning system based on project-based learning (PBL) by technical puzzle. This will affect a greater time commitment within the course to carry out the project (sessions will be needed to make the expert meetings, to take time for explanation of an expert to the other members forming the group, etc.), but it will result in an improvement from the point of view of learning.

- Conduct a peer assessment set by the students enrolled in the course. Until now, assessment has been carried out by course professors involved in the cross project. It is not excluded, however, that part of the final grade of the cross project is carried out by course students themselves.

- Open students' dissertations from previous semesters. This will allow to see what advanced students of the same degree have done. This would undoubtedly stimulate, encourage, and motivate these new students, who would see firsthand the "applicability" of their qualifications.

\section{CONCLUSION}

This article has shown the inclusion of the sizing and design of renewable energy systems in the context of the Bachelor Degree in Energy Engineering, offered at the at the Eastern Barcelona School of Engineering (Escuela de Ingeniería de Barcelona Este - EEBE) of the Technical University of Catalonia - BarcelonaTech (UPC).

In particular, and although this topic was eventually abandoned in the initial degree curriculum, the paper focuses on the development of a $3^{\text {rd }}$-year course, Renewable Energies. The results obtained during four years of teaching of the aforementioned course, can confirm, on the one hand, the good acceptance of the course among Energy Engineering students, and, on the other hand, the good academic results obtained by them.

\section{ACKNOWLEDGMENT}

This work has been partially supported and funded by the Spanish Ministerio de Economía y Competitividad by projects DPI2013-47799-C2-2-R and DPI2016-78957-R, and the LOGIMATIC EU project H2020-Galileo-2015-687534.

\section{REFERENCES}

[1] EHEA official website: Bologna Process - European Higher Education Area. Available: http://www.ehea.info/

[2] ERIC - Institute of Education Sciences website: The Bologna Process for U.S. Eyes: Re-learning Higher Education in the Age of Convergence. Available: https://eric.ed.gov/?id=ED504904

[3] European Commission: European Credit Transfer and Accumulation System (ECTS). Available: http://ec.europa.eu/education/resources/european-credit-transferaccumulation-system en

[4] Eastern Barcelona School of Engineering (Escola d'Enginyeria de Barcelona Est, EEBE) website. Available: http://eebe.upc.edu/en

[5] Barcelona College of Industrial Engineering (Escola Universitària d'Enginyeria Tècnica Industrial de Barcelona, EUETIB) website. Available: http://www.euetib.upc.edu/

[6] Eastern Barcelona School of Engineering (Escola d'Enginyeria de Barcelona Est, EEBE): Energy Engineering Degree Curriculum. Available: http://www.upc.edu/learning/courses/Bachelors-degrees/energyengineering-barcelona-eebe?set language $=$ en

[7] Eastern Barcelona School of Engineering (Escola d'Enginyeria de Barcelona Est, EEBE): Renewable Energies Course Syllabus. Available: http://www.upc.edu/estudispdf/guia docent.php?codi=295302\& lang=ing 